\title{
WAR WITHIN, WAR WITHOUT: RUSSIAN REFUGEE RABBIS DURING WORLD WAR I
}

\section{Andrew N. Koss}

After the outbreak of World War I in 1914, Rabbi Ya'akov Landa was one of some 250,000 Russian Jews who had fled, or been forcibly expelled, from their homes in Russia's western provinces to settle in the country's interior. ${ }^{1}$ After Landa's exile, he spent several months traveling amid refugee communities in Voronezh, Tambov, Penza, Saratov, and Samara provinces. At the conclusion of his journey, he composed a detailed report about the state of religious observance among the refugees, which he sent to Rabbi Shalom Dov-Ber Schneerson of Lubavitch. ${ }^{2}$ Landa's observations during these months shocked his core sensibilities as a rabbi and an observant Jew. He noted that refugees were disregarding such fundamental aspects of Jewish practice as Sabbath observance and were living without the basic institutions that had traditionally defined religious and communal life.

In community after community, Landa noted the same phenomena: traditional Jewish schooling abandoned, the absence of ritual baths or mikvehs, and a dire shortage of rabbis and kosher slaughterers. In several cases, he questioned the piety and competence of the rare ritual slaughterers who could be found, and occasionally he called attention to the capabilities even of the rabbis. ${ }^{3}$ Many locales lacked synagogues or had insufficient room in existing synagogues for the hordes of newcomers. Furthermore, the administrators of Jewish charitable organizations to which Jews flocked for much-needed support

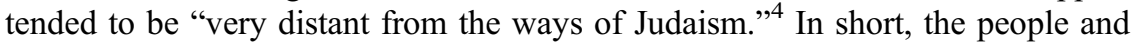
places necessary for the maintenance of normal religious observance were gone.

1. Semion Goldin, "Deportation of Jews by the Russian Military Command, 1914-1915," Jews in Eastern Europe 1, no. 41 (2000): 58. The figure of 250,000 is most likely a conservative estimate. See notes 10 and 11 below.

2. The undated report can be found in Shalom Dov-Ber Schneerson, Igrot-kodesh, vol. 5 (Brooklyn, NY: Kehot Publication Society, 1987), 63-81 (hereafter cited as Igrot Rasha"b). The editors speculate (I believe accurately) that it was written in the winter of 1916-17, reporting on visits made over the previous nine months (pp. 62-63 footnote).

3. Ibid., 70, 76, 78, 79, 81 .

4. Ibid., 74 . 


\section{Andrew N. Koss}

Both the rhetoric and content of Landa's report suggest that his observations went beyond his lamenting of impiety or declining religious observance. He had, instead, identified a new pattern of religious laxity that resulted directly from wartime circumstances. His description of a religious crisis during World War I forms a rabbinic parallel to the picture of moral and societal disintegration apparent in other literary reports, memoirs, and journalistic Jewish sources of the period. ${ }^{5}$ It was not the seductive pull of secular ideologies on Jewish youth that Landa regarded as the primary corrosive force undermining traditional Judaism. Nor was it the trend among well-to-do families to attempt to imitate the mores of the non-Jewish bourgeoisie. Rather, it was geographic and economic dislocation that posed the greatest threat. Jews who had never objected to traditional observance in principle were caving in to enormous material pressures:

While one son is employed in the shop of a non-Jew and does his work on the Sabbath as on any workday, the second son [works] for one of the [native] Jewish residents and does his work on the Sabbath as on any weekday, and sometimes their father, too, is like that. It should thus not be surprising that the feelings of holiness of the Jewish people on the Sabbath day are lost from their memories. . . . It is self-evident that public desecration of the Sabbath is a growing plague (the Merciful One be with them!) that is enveloping more and more [Jews] in its net—may God grant them atonement. ${ }^{6}$

It thus seemed to Landa that the vast majority of refugees who had faithfully observed the commandments in their home communities now ceased to do so in exile. Although quantitative data to support his claims is lacking, the evidence is ample and persuasive. Refugees violated the Sabbath, according to Landa, because they now resided in places where both Jewish and non-Jewish employers expected employees to work on that day. Furthermore, he claimed that the impact of the war went beyond outward observance to inward experience, robbing Jews of the very memory of the Sabbath's sanctity.

In the passage quoted above, Landa distinguished between refugees from the Pale of Jewish Settlement and those who had been living outside it, in the Russian interior, prior to the war. He drew this distinction because the Pale- an area comprised of the empire's westernmost provinces - contained Russia's most traditional Jewish population, and thus was a region where Jews were expected to observe the commandments. While Jews tended to perceive the

5. See, for example, Pinkes far der geshikhte fun Vilne in di yorn fun milkhome un okupatsye, ed. Zalmen Reisen (Wilno: Di historish-etnografishe gezelshaft oyfn nomen fun Sh. An-Ski, z"1, 1922); also S. An-sky, Der yudisher khurbn fun Poylen, Galitsiye un Bukovina, fun tog-bukh 1914-1917, in Gezamelte shriftn, 15 vols. (Vilna: Ferlag "An-ski," 1920-1925), vols. 4-6. For an analysis of Jewish literature of World War I, see David G. Roskies, Against the Apocalypse: Responses to Catastrophe in Modern Jewish Culture (Cambridge, MA: Harvard University Press, 1984), 115-21, 129-32, 134-41. See also Jillian Vanessa Davidson, “'A Secular Catastrophe' in Eastern Europe: The Great War and the Reconstruction of Modern Jewish Memory" (Doctoral dissertation, Jewish Theological Seminary of America, 2004).

6. Igrot Rasha" b, vol. 5, 65. 
residential restrictions that made it difficult for them to settle in the Russian interior as a harsh burden imposed by an unfriendly government, they also regarded the Pale as a bastion of authentic Jewish life. ${ }^{7}$ And although rabbis in the Pale had been engaged in a fierce struggle with the forces of modernization since the middle of the nineteenth century, they still counted on the support of the masses. Landa's findings, however, suggested that this support had now crumbled and that the rank and file-driven from the Pale in large numberswere defecting.

By no means was Landa alone in his concerns; such worry was widespread among contemporary rabbis who noted a precipitous decline in religious observance during the war years, both among refugees and among those who remained in the ravaged territories on the Russian frontier. In the eyes of these rabbis, the destruction of traditional life in the Pale was a crisis of international proportions. The Jews of this territory, besides constituting a large portion of the global Jewish population, probably formed the largest existing mass of traditionally religious Jews. Outside the Pale - in the Russian interior, in Western Europe, or in America - only a minority clung strictly to religious observance; by contrast, observance in the Pale was the path of the majority. Here Jews not only kept the Sabbath, but tended also to live in insular Jewish communities and to prefer Yiddish as their language. Numerous towns and cities were recognized for their pious residents and great rabbis, or were famous as the locations of hasidic courts or yeshivas. In the minds of defenders of Orthodoxy, ${ }^{8}$ the Pale, together

7. This perception of the Pale was not limited to rabbis or the Orthodox. For attitudes of acculturating Jews living in St. Petersburg toward the Pale, see Benjamin Nathans, Beyond the Pale: The Jewish Encounter with Late Imperial Russia (Berkeley: University of California Press, 2002), 147, 167-68, 190-91, and 378-79. The very fact that, in 1911, S. An-sky launched an ethnographic expedition through the Pale to document Jewish customs, folklore, and folk art bespeaks a belief in the Pale as a repository of Jewish authenticity. See Abram Rechtman, Yidishe etnografye un folklor: zikhroynes vegn der etnografisher ekspeditsye ongefirt fun Sh. An-ski (Buenos Aires, Argentina: Jewish Institute of Learning, 1958).

8. For the purposes of this article, I will use the terms Orthodox and Orthodoxy to refer to those who consciously espoused an ideology that was opposed to significant religious innovation. On the eve of World War I, most rabbis in Russia and Congress Poland could be considered Orthodox, while most of the religiously observant lay population would best be described as traditional. For scholarly approaches to this distinction, see Jacob Katz, "Orthodoxy in Historical Perspective," in Studies in Contemporary Jewry 2: The Challenge of Modernity and Jewish Orthodoxy, ed. Peter Medding (Bloomington: Indiana University Press, 1986), 4-17; Michael K. Silber, "The Emergence of Ultra-Orthodoxy: The Invention of a Tradition," in The Uses of Tradition: Jewish Continuity in the Modern Era, ed. Jack Wertheimer (Cambridge, MA: Harvard University Press, 1992), 23-84; Gershon C. Bacon, The Politics of Tradition: Agudat Yisrael in Poland, 1916-1939 (Jerusalem: Magnes Press, Hebrew University, 1996); Haym Soloveitchik, "Rupture and Reconstruction: The Transformation of Contemporary Orthodoxy," Tradition 28, no. 4 (Summer 1994): 64-130. Mordechai Altshuler, "ha-Politikah shel ha-maḥaneh ha-dati veha-ḥaredi be-Rusyah bi-shenat 1917," Shvut 15 (1992): 195-234 provides an extensive discussion of Orthodox political organization in Russia in 1917 and briefly acknowledges some of the effects of World War I. Altshuler, however, does not consider the long-term effects of the war on East European Jewish Orthodoxy, the subject of the present study. To date, virtually no other secondary literature about Orthodox Judaism during World War I exists. 


\section{Andrew N. Koss}

with the adjoining Kingdom of Poland, ${ }^{9}$ was the heartland of Jewry and of Judaism itself. If tradition could not be maintained among Jews of this region, how could the Jewish religion and culture survive at all?

The religious crisis came directly out of a general catastrophe that engulfed the Russian Empire as a whole - and Russia's Jews in particular-with the outbreak of war in 1914. By order of the tsar, the territories closest to the front lines - a major portion of the Pale of Settlement - were placed under the control of a military government with vast powers and deep hostility toward Jews. In 1915, the military crafted a program to expel Jews from the war zone. Hundreds of thousands were driven from their homes, often violently, with little warning and without plans for future settlement. Then, in the wake of a series of strategic defeats at the hands of the Germans, the Russian army pulled back hundreds of miles to more defensible lines, deeper within the Pale. During this Great Retreat, it carried out a scorched-earth policy that left bridges destroyed, storehouses burned, and factories dismantled. Dejected troops, especially Cossack units, vented their anger on the Jewish communities through which they passed, engaging in bloody binges of rape, looting, and murder. Contemporary accounts of these incidents are more reminiscent of seventeenth- and eighteenth-century massacres than of the pogroms of the 1880 s or $1904-1907 . .^{10}$

In addition to those who were expelled outright, many Jews fled voluntarily from the German advance. By 1916, more than 250,000 Jews had fled or been expelled from Russia's western provinces; most took refuge in eastern Ukraine or in adjoining provinces beyond the Pale where, after more than a century of exclusion, they were finally allowed to settle at will. Massive migration and the difficulties of travel broke up old communities, separating friends and family members. Entire yeshivas and hasidic courts either disbanded or relocated eastward. ${ }^{11}$ For the most part, the refugees arrived with very little money and few

9. This area, alternatively known as "the Congress Kingdom," "Congress Poland," or simply "Poland," and officially designated Privislianskii krai (Vistula Land) after 1863, was not technically part of the Pale. However, Jews were allowed to reside there with relatively few restrictions. For most of the discussion here, what was true for the Pale was also true for Congress Poland.

10. No comprehensive work covering this episode of Jewish history exists at this time. The best available works are Salo W. Baron, The Russian Jew under Tsars and Soviets (New York: Macmillan, 1976), 156-67; Steven J. Zipperstein, "The Politics of Relief," in Studies in Contemporary Jewry 4: The Jews and the European Crisis, 1914-1921, ed. Jonathan Frankel (Bloomington: Indiana University Press, 1988), 22-40; Eric Lohr, "The Russian Army and the Jews: Mass Deportation, Hostages, and Violence during World War I," Russian Review 60, no. 3 (July 2001): 404-19; Simon Dubnov, "Iz 'chernoi knigi' rossiiskago evreistva: Materialy dlia istorii voiny 1914-1915 g.," Evreiskaia starina 10 (1918): 195-296.

11. Ibid. In August 1915, the Russian government allowed Jewish refugees to settle outside the Pale (Zipperstein, "The Politics of Relief," in Frankel, Studies in Contemporary Jewry, 25). For expulsions, see Goldin, "Deportation of Jews," 40-72. For expulsions from Galicia, see Alexander Victor Prusin, Nationalizing a Borderland: War, Ethnicity, and Anti-Jewish Violence in East Galicia, 19141920 (Tuscaloosa: University of Alabama Press, 2005), 48-62. For yeshivas, see Mosedot Torah be-Eiropah, ed. Samuel K. Mirsky (New York: Histadruth Ivrith of America, 1956). For hasidic courts, see Aaron Ze'ev Aescoly, ha-Hasidut be-Polin (Jerusalem: Hebrew University, 1998), 125-27. 
possessions. The areas in which they settled, as was true of the rest of the empire, were sinking into the economic crisis that would soon lead to the February Revolution of 1917.

Thus it was in the midst of a general Russian crisis, with particularly severe consequences for Russian Jewry, that Landa, along with other members of the rabbinic leadership, identified a specifically religious crisis, one that threatened the continued existence of Judaism as they knew it. The disintegration of crucial aspects of Jewish observance meant that the traditional world was itself disappearing, and that Orthodoxy was losing its base of supporters. This article explores the ways in which rabbis in the Russian Empire evaluated and responded to the deterioration of religious practice during World War I, and, in doing so, took steps that would radically transform East European Orthodoxy. World War I was a watershed in the history of religious Judaism in the Russian Empire-a moment in the struggle between the traditional rabbinate and the forces of modernization in which the former reevaluated its positions and reformulated its strategies. On the one hand, part of the new strategy entailed adopting a more aggressive approach to protecting the religious way of life. On the other hand, rabbis opted to make major concessions, including some they had fought vigorously against for decades.

In the half-century preceding World War I, Russia's traditionalist rabbis tended to react to the threat of innovation by staking out stricter, more extreme positions. They waged a fierce battle against modernization, focusing their efforts on the educated elite through introducing innovations to the yeshiva (an institution attended only by a small minority) or polemics in the Hebrew press (which could be read only by the yeshiva-educated and a handful of others). ${ }^{12}$ World War I saw a reversal of both these tendencies. It led Orthodox rabbis to support reforms that seemed tepid to outsiders but were, in fact, groundbreaking precisely because previously they had been resisted so fiercely. The circumstances also forced rabbis to bring their antimodernization efforts to a broader populace, not just the educated elite. In order to do so, they created new and modern organizational structures, giving Orthodoxy many of the characteristics of a political movement.

The nature of wartime compromise is illustrated by the changes in rabbinic attitudes toward secular education. In reaction to the Haskalah (Jewish Enlightenment) movement of the eighteenth and nineteenth centuries, many rabbis who had regarded secular learning as benign but irrelevant now considered it inherently pernicious. Once they began to associate the acquisition of secular knowledge with an ideological threat to the religious status quo, they began to perceive it

12. Shaul Stampfer, ha-Yeshivah ha-Lita'it be-hithavutah (Jerusalem: Merkaz Zalman Shazar le-toledot Yisra'el, 2005); Eli Lederhendler, Jewish Responses to Modernity: New Voices in America and Eastern Europe (New York: New York University Press, 1994), 67-103. For other Orthodox responses, see Eli Lederhendler, "The Vilna Rabbis' Anti-socialist Appeal, June 1903," Shvut 15 (1992): xxxiii-xl; ChaeRan Freeze, Jewish Marriage and Divorce in Imperial Russia (Lebanon, NH: University Press of New England for Brandeis University Press, 2002), 243-79 
as dangerous. ${ }^{13}$ Yet, during the war years, some of the very rabbis who had been at the forefront of protest against any educational reform endorsed the introduction of limited secular education into religious schools in order to defend Orthodoxy. Such rabbis saw these concessions as part of a tactical retreat, intended to shore up their weakening position.

In the course of their wartime activities, these otherwise quite conservative rabbis joined forces with a small number of relatively liberal rabbis who supported such innovations as secular education on ideological, rather than pragmatic, grounds. These rabbis were more likely than most to seek limited accommodation with modernity within the framework of tradition and were less willing to react against change by taking more stringent positions. Such moderates were firmly Orthodox and completely integrated into the Russian rabbinate; it was only later that they would begin to be considered a distinctive group or movement. The collaborative efforts of both staunchly conservative and more moderate rabbis permanently changed the face of Jewish Orthodoxy in Eastern Europe.

Most documentary records of rabbinic activity during the war years are found in correspondence between rabbis, in letters from rabbis to lay leaders, and in public announcements circulated in the Orthodox press. The bulk of these documents share one overarching methodological problem: Because Orthodoxy made a fundamental, implicit claim to being unchanging, rabbinic rhetoric always minimized innovation. Therefore, although some of the proposals contained within these sources were in fact quite radical, their authors never actually heralded them as such.

In addition, there exists an additional methodological hurdle to the study of this topic: scant attention paid to religious life in contemporary Jewish sources that were not explicitly Orthodox. During and shortly after World War I, Jewish writers produced a substantial body of written documentation recording the events of these extraordinary years, yet most of these works were produced by a modernizing intelligentsia who took little interest in developments within Orthodoxy or in the attenuation of religious observance. The reasons for this neglect were simple: Such writers viewed Orthodoxy as marginal to the core narrative of Jewish progress and enlightenment to which they subscribed. They thus ascribed limited relevance to changes in the Orthodox scene, and considered lapses in religious practice as part of history following its natural course. ${ }^{14}$ Although this silence

13. See Jacob Katz, Out of the Ghetto: The Social Background of Jewish Emancipation, 17701870 (Syracuse, NY: Syracuse University Press, 1998), 142-60. For examples of such rabbinic attitudes, see Naḥman of Braslav, Likute Mohara"n 64:2-4 (New York: 1966), 181-83; Ezekiel Landau, Tsiyun le-nefesh hayah to Berakhot 28b (Prague: 1828), 39a-40a. For Orthodoxy and secular education in Hungary, see Silber, "The Emergence of Ultra-Orthodoxy" in Wertheimer, Uses of Tradition, 35-37, 43-44, 61-62. For attitudes of Lithuanian rabbis, see Jacob J. Schacter, "Haskalah, Secular Studies and the Close of the Yeshiva in Volozhin in 1892," Torah u-Madda Journal 2 (1990): $76-133$.

14. An illustrative example of such an attitude can be found in an article by Zionist journalist Joseph Heftman on the Masoret ve-herut conference, discussed at length below. Heftman argued that support for a new Orthodox political party did not signify an important change within —or a resurgence of - Orthodoxy, but rather a reaction by the bourgeois majority to the "lefticization" (entlinkung) of Jewish political life. Thus, one of very few reports on rabbinic activities from the secular Jewish 
was by no means complete, it translated into a gap between Orthodox and nonOrthodox narratives of the war. Consequently, the historian must navigate between Orthodox sources that ignore history and secular sources that ignore Orthodoxy.

To transcend these difficulties, this article focuses on the activities of three remarkable, but very different, rabbis who left behind usable historical documents. The first is Landa's correspondent, Shalom Dov-Ber Schneerson (1860-1920), rebbe of the Lubavitch (Liubavichi) hasidim - the largest of the Lithuanian hasidic sects-whose substantial network of followers stretched throughout Lithuania and Russian Ukraine. The second, Hayim Ozer Grodzienski (18631940), by dint of his talmudic erudition, active involvement in communal affairs, and position as head of the rabbinic court of Vilna, was widely recognized as the leader of Lithuanian mitnagdic (nonhasidic) Jewry. ${ }^{15}$ Both stood at the forefront of the battle against secularization. Their correspondences, approaching a wide variety of issues, are available in published form. ${ }^{16}$

The third rabbi, Yehudah Leyb Graubart (1861-1937), was notably different. A member of a prominent family of rabbis, he had attracted attention in rabbinic circles prior to the war because of his talmudic writings and responsa. ${ }^{17}$ While Graubart became known in his rabbinic posts for his vociferous public protestations against Sabbath desecration, he also read works of classical Jewish philosophy and developed an interest in modern Hebrew literature. Although he was involved in Orthodox organizational activities in the prewar years, he never attained a profile comparable to that of Grodzienski or Schneerson. Between 1916 and 1919, however, Graubart traveled across Russia, agitating for the Orthodox cause and garnering support from the highest levels of rabbinic and lay leadership. In 1920, he left Europe to serve as a rabbi in Toronto and St. Louis. In North America, he played a marginal role in organized Orthodoxy, although he was a vocal supporter of religious Zionism - a position that had come to be associated with liberal trends within Orthodox Jewry.

press downplayed the religious aspect. Heftman instead went on to interpret the party's creation as evidence of strong support for Zionism among the Jewish masses, i.e., as proof of the popularity of his own ideology. Yosipon [Joseph Heftman], "Di yudishe ortodoksye in Rusland," Dos yudishe folk 24 (August 9, 1917): 3. For a contrary analysis by another Zionist observer, see Moshe Kleinman, Ben lehavot: ba-milhamah uva-mahpekhah (Tel Aviv: "Yavneh," 1943), 232-39, especially 235-36. (This piece originally appeared in Unzer leben [Odessa], July 18-19, 1917.)

15. Here and elsewhere, unless otherwise specified, by "Lithuania" I mean the Jewish cultural region of greater or historic Lithuania, which approximately corresponds to modern-day Lithuania, Latvia, and Belarus.

16. For Schneerson's correspondence, see note 2. Most of the letters cited here come from the last of the five published volumes of his letters, which primarily consists of correspondence from 1916 to 1918. This volume also includes a useful forward discussing Schneerson's activities during this period. Grodzienski's correspondence can be found in Ahie 'ezer: kovets igrot, ed. Aharon Suraski, 2 vols. (Bene Berak: Netsah, 1970); the second volume contains a biographic sketch by the editor.

17. Over the course of his life, Graubart published several volumes of talmudic scholarship under the title of Havalim ba-ne imim; the first was published in Piotrków in 1901. 


\section{Andrew N. Koss}

Graubart detailed his activities during the war years, along with his impressions of the situation of Polish and Russian Jewry, in his memoir Sefer Zikaron, which is probably the most significant extant account of the war in Russia from an Orthodox perspective. ${ }^{18}$ This work is in itself noteworthy because the memoir was not a traditionally accepted genre of rabbinic literature. His memoir was, however, one of several autobiographical works produced by rabbis in the aftermath of the war. And although only Graubart's makes the war the focus of its narrative, this modest boom in memoir writing may have stemmed from recognition that World War I constituted a sharp break with the past. These memoirs sought either to record the events of this period of upheaval or to preserve the memory of the bygone prewar years. In both cases, their authors turned to memoir - and thus to history, as they were concerned not merely with their personal stories but also with the fate of their communities - out of a belief that the Old World of traditional religiosity had been shattered ${ }^{19}$ (a point one such memoirist ${ }^{20}$ made explicitly). In Sefer Zikaron, Graubart endeavored to record the specific effects of the war on religious life and his own participation in engineering an Orthodox response. His words thus provide a counter-narrative to lay war literature.

In his postwar writings, Graubart hammered out an ideology (discussed below) that would harmonize the acceptance of some elements of modernization with strict religious observance, favoring improved relations with the non-Jewish

18. Yehudah Leyb Graubart, Sefer zikaron: reshumot mi-yeme ha-milhamah ha-aharonah ve-hashkafot shonot u-mikhtavim (Łódź: Mesorah, 1926). Hereafter cited simply as Graubart.

19. Rabbi Jacob Emden's Megilat sefer (written between 1752 and 1766) is the best-known example of rabbinic autobiography. In general, the genre is quite rare. Among the most interesting examples appearing immediately after World War I (in addition to Graubart's) are Ya'akov Lipschitz, Zikhron Ya 'akov: historiyah Yisre'elit me-haye ha-Yehudim be-Rusya u-Polin shenot 520-656, 17601896 (Kaunas: 1924-30) (Volume 1 printed by David Draller of Frankfurt am Main. Volume 2 printed by Sh. Yoselevits of Kaunas Volume 3 printed by Y. Kuznitski and L. Beyles of Kaunas.); Barukh Epstein, Mekor barukh (Wilno: Rom, 1928); and Ya'akov Mazeh, Zikhronot (Tel Aviv: Yalkut, 1936). Lipschitz died in 1921 and Mazeh in 1924; Epstein began work on Mekor barukh during World War I itself. Thus, these works were created in close temporal proximity to the war. Lipschitz and Epstein dealt exclusively with the pre-World War I era, and added histories of events before their own births to their personal memories, while Mazeh paid little attention to the war itself. For an analysis of these works as memoir, see Marcus Moseley, Being for Myself Alone: Origins of Jewish Autobiography (Stanford, CA: Stanford University Press, 2006), 377-412. Perhaps there is an analogy between the rabbinic turn to memoir after World War I and the turn to history following the expulsion from Spain posited by Yosef Hayim Yerushalmi in Zakhor: Jewish History and Jewish Memory (Seattle: University of Washington Press, 1996), 57-75. Mention should also be made here of Khaykl Lunski's Fun vilner geto; geshtaltn un bilder geshribn in shvere tsaytn (Wilno: Farlag fun dem fareyn fun di Yidishe literatn un zshurnalistn in Vilne, 1920). Although not a rabbi, and not particularly affiliated with organized Orthodoxy, Lunksi was himself strictly observant and filled his chronicle of the war years with rich descriptions of the impact of the war on Jewish religious life.

20. Epstein, Mekor barukh, vol. 1, 1-2. This passage can be found in the preface to the 1928 edition, which does not appear in the 2004 edition. 
world and encouraging the acquisition of secular knowledge. ${ }^{21}$ The war had given him the opportunity to experiment with such new concepts. Grodzienski and Schneerson, by contrast, had a more firm, conservative orientation that would today be described as ultra-Orthodox.

While these rabbis represented three different ideological trends-hasidic, mitnagdic, and religious Zionist - they enjoyed mutual respect and cooperation during the war years. They also shared a common experience of the war: All were native to the heavily Jewish western provinces, and at the outset of the conflict, each held rabbinic posts; and all three fled to the Russian interior during the Central Powers' advance. In exile, they came into contact with a broad crosssection of Russian Jewry, including refugees from various regions and local Jews who held diverse political and religious orientations. The rabbis' wartime activities and postwar reflections, together with other contemporary rabbinic correspondence and writings, show how quickly they and their supporters grasped the magnitude of the crisis. Their impressions also illustrate how a collective rabbinic response was tailored to new circumstances and threats to allow them to defend their old beliefs and ways of life.

\section{IDENTIFying A Religious CRisis}

As Jewish refugees tried to settle into new homes beyond the Pale, they sought out towns and cities with existing Jewish communities and often received support from local Jews upon arrival. These havens tended toward less widespread and less stringent religious observance in comparison with the refugees' native shtetlekh. It was very difficult for new arrivals to find sources of livelihood in the impoverished east. Many, if not most, relied on charity distributed by Jewish relief organizations. $^{22}$

Rabbi Schneerson was among the Jews who fled eastward during the Russian retreat. He left Liubavichi, which had been the seat of his dynasty's hasidic court for five generations, to take refuge in Rostov-on-Don. Many of his hasidim were among the thousands of Jewish refugees streaming into that city during the war. Rostov was a popular destination, both because it was located just beyond the Pale and because it already had a sizeable Jewish population. Prior to the outbreak of the war, Jews had taken part in Rostov's rapid economic growth, and it boasted a number of prominent Jewish industrialists and businessmen. Jews even were members of the municipal council. Yet, despite the fact that in 1914 Rostov had a Jewish population of 16,226, it had only two synagogues and one shtibl (small prayer house), offering just one place of worship for every 5,400

21. See in particular Sefer yamin u-smo'l: ma'amarim bi-sh'elot ha-hayim be-mahaneh Yisra'el ve- 'al asher ben Yisra'el le- 'amim (Łódź: Mesorah, 1930). For biographic data on Graubart, see N. Shemen, "Rabeynu Yehude Leyb Groybart zts"1 in lebn un shafen," in Yoyvl bukh: 25 yoriger yubiley talmud toyre "Eyts khayem" (Toronto: Jubilee Committee, 1943), 13-45 and Stephen A. Speisman, The Jews of Toronto: A History to 1937 (Toronto: McClelland and Stewart, 1979), 278-92 passim.

22. Graubart, 25-40, 271-332. For the treatment of refugees, Jewish and non-Jewish, see Peter Gatrell, A Whole Empire Walking: Refugees in Russia during World War I (Bloomington and Indianapolis: Indiana University Press, Indiana Michigan Series in Russian and European Studies, 2000). 


\section{Andrew N. Koss}

Jews. $^{23}$ (In contrast, in 1910, Vilna had 104 officially registered Jewish places of prayer for 63,840 Jews, or about 1 per 610 Jews, in addition to untold numbers of unregistered shtiblekh. $)^{24}$ Similarly, although the size of the Jewish population had increased steadily since the turn of the century, the number of heders had decreased. ${ }^{25}$ In other words, Rostov was a city with a thriving Jewish population, but without the tradition-steeped environment that characterized the places from which the new refugees had come.

Observing the lack of traditional Jewish schools in Rostov and aware that it would be difficult for refugee parents to establish such schools in their new homes, on March 9, 1916, Schneerson summoned Landa—one of his chief advisers ${ }^{26}$ and sent him on an expedition through the refugee communities to distribute funds for the establishment and maintenance of religious schools.

As a result of this expedition, Landa came to confront the systemic religious decline that became the main subject of his report. In evaluating the issue of Jewish education, he noted that heders and Talmud Torahs were few and far between and always underfunded. The vast majority of Jewish children who attended school at all did so at a variety of secular or semisecular institutions, mostly run by the Society for the Promotion of Enlightenment among Jews (OPE) and other charitable organizations; many of these schools had a decided Zionist or Yiddishist bent. Landa took pains to interview schoolchildren and report on their curricula, teachers, and such procedural issues as whether students covered their heads when studying sacred texts. Although most of the schools he took note of taught some religious subjects, inevitably these took a back seat to secular studies. In at least one instance, a school cafeteria served nonkosher meat. Landa concluded that the schools he investigated were at best denying Jewish children a proper religious education and at worst were pernicious incubators of heresy. ${ }^{27}$

While, as we have seen, Landa provided details about the lack of Sabbath observance, he did not say whether Jews without access to kosher meat were abstaining from meat altogether or simply patronizing nonkosher butchers. It

23. E. V. Movshovich, Ocherki istorii evreev na donu (Rostov-on-Don: Donskoi izdatel'skii dom, 2006), 57-58, 62-63, 83-84; Oleg Budnitskii, "The Jews in Rostov-on-Don in 1918-1919," Jews and Jewish Topics in the Soviet Union and Eastern Europe 19 (1992): 16-17.

24. Israel Klausner, Vilnah: Yerushalyim de-Lita: dorot aharonim, 1881-1939, vol. 1 (Tel Aviv: Ghetto Fighters' House, 1983), 93.

25. Movshovich, Ocherki istorii evreev na donu, 57, 60.

26. Landa's position as "court rabbi" (rav he-hatser) meant that he was responsible for all halakhic questions that arose in the rebbe's home and court. Previously he had also held the post of rabbi of Kurenets. In 1936, he was made chief rabbi of Bene Brak. He was well known for his rulings on the subject of mikvehs and for reputedly possessing quasi-mystical medical powers.

27. Igrot Rasha" $b$, vol. 5, 66-69, 72-78, 80. For OPE activity during the war, see Zipperstein, "The Politics of Relief," in Frankel, Studies in Contemporary Jewry, 30-31 and 35-36. For secular Yiddish schools in particular, see Kh. Sh. Kazdan, Fun kheyder un "shkoles" biz Tsysho: dos ruslendishe yidntum in gerangl fun shul, shprakh, kultur (Mexico: Shlomo Mendelson fond bay der gezelshaft far kultur un hilf, 1956), 208-16. 
seems a likely inference, however, that many took the latter route. ${ }^{28}$ As to whether conjugal relations continued in the absence of mikvehs, Landa did not dare speculate. For traditional Jews, these three sets of religious regulations - the laws of kashrut, Sabbath observance, and family purity - combined to permeate daily life with religious observance. The abandonment of this ritual rubric, along with atrophied synagogue attendance and limited Jewish education, meant that there was very little left of traditional Judaism for the refugees.

The Jews Landa encountered had generally adhered to Jewish rites and regulations when the proper institutions had existed, but now were, in a sense, being forced out of observance, or being seduced by new opportunities. Any given community might have a handful of pious individuals who would go to heroic lengths in their devotion to Jewish law-abstaining from meat and sex until normal conditions returned, gathering fellow Jews in a crowded room to pray, praying by themselves when this was impossible, and so on-but such religious heroism could not reasonably be expected of the masses.

Like Landa, Yehudah Leyb Graubart, the exiled rabbi of Staszów in Radom province, was appalled as he traveled through the eastern refugee communities in the fall of $1915 .^{29}$ The following summer, he delivered a sermon admonishing refugees living in Kazan' for "desecrating the divine name" with their laxity in Sabbath observance, which he attributed directly to wartime conditions. He told them that when native Jews saw those who had come from "a place of Torah and religion" (i.e., Poland and the Pale) violating the Sabbath, they would feel justified in doing the same. Graubart was sympathetic enough to the plight of the refugees to realize that Sabbath observance had become a nisayon, a test of faith, for them. After all, he acknowledged, they would have been embarrassed to break the Sabbath back home in Poland or Lithuania. Furthermore, in their former communities no stores would have been open for them to shop in; even peasants from surrounding villages, knowing that Jews closed their shops for the Sabbath, would not come to town to trade on Saturday. But he stressed that a lack of social or economic disincentives did not absolve them from the charge of disobedience. The essential tragedy of the war, he told the Jews of Kazan', was not the admittedly severe physical and material suffering it brought about, but, instead, the "spiritual distress." 30

During the first year of the war, prior to his deportation to the interior by the authorities, Graubart repeatedly intervened with Russian officials to protect his flock from persecution. During the brief Austrian occupation of Staszów, he collaborated with the town's priest to keep cooperation with the Habsburg military to a minimum - trying to walk a tightrope between appeasing an occupying military and exposing their congregations to accusations of disloyalty if the Russians returned. When the Russian army retook the city, the military authorities took

28. This is particularly interesting when compared with S. An-sky's certainty that many or most Polish and Galician Jews in situ would under no circumstance eat at nonkosher soup kitchens, An-sky, Khurbn Galitsiye, in Gezamelte shriftn, vol. 4, 65-66, 70, 80-81.

29. Graubart, 33-59.

30. Ibid., 279-80. 
Graubart hostage in order to guarantee the loyalty of the town's Jews; thus he experienced the cruelties of war firsthand. ${ }^{31}$ Once in exile, he saw that nondenominational relief organizations were already managing, to the extent possible, the humanitarian crisis facing the Jews. As a rabbi, he saw his task as helping Jewish refugees maintain their faith in a spiritual wilderness, and combating what he saw as threats to Judaism itself.

In other sermons given to refugee communities at that time, Graubart, like Landa, complained of the refugees' inattentiveness to family purity and religious education. By the end of 1916, the two rabbis were in contact with each other and were doing what they could to alert the rabbinic establishment to what they saw as a severe and dangerous crisis. ${ }^{32}$

This crisis was by no means limited to refugees. The war also had a devastating effect on Jews who remained in Poland and the Pale. While the stalemate on the Western Front meant that (after a few well-publicized incidents in 1914) civilian populations could remain relatively safe from the fighting, the mobility of the Eastern Front went hand in hand with frequent shelling of towns and villages by both sides, in addition to attacks on Jews by Russian soldiers. The war closed down major commercial routes, leaving many Jews without their primary sources of livelihood. Shortages of basic goods became widespread. Able-bodied males not drafted into military service were often put to work digging trenches or assisting in military hospitals. In areas that came under German occupation, requisitions, forced labor, and harsh restrictions on trade and movement led to mass pauperization, outbreaks of disease, and even starvation. The unsavory trades of smuggling and prostitution gained central economic importance. Schools, heders, and yeshivas, along with other institutions, often ceased to function. ${ }^{33}$

In addition, the occupation took a specific toll on religious life. Synagogues and study halls had to be transformed into shelters for refugees and the homeless, or remained empty because congregants were too hungry to attend, had been taken away for forced labor, or had died of privation or illness. ${ }^{34}$ Barukh Epstein, a wellknown rabbinic scholar, recalled forsaking talmudic studies during the period of German rule. ${ }^{35}$ Furthermore, forced labor generally entailed working on Saturdays. In certain locales, the German administration forced Jews to keep their stores open then, and thus, as one secular memoirist put it, "the psychological fear of Sabbath desecration was broken."36

31. Ibid., 10-27.

32. Ibid., 26-95; Igrot Rasha"b, vol. 5, 60-83.

33. An-sky, Der yudisher, in Gezamelte shriftn, vol. 6, 17-18, 30; Graubart, 180ff; Roskies, Against the Apocalypse, 115-21, 129-32, 134-41; Pinkes far der geshikhte, ed. Reisen, 1-204; Lunski, Fun vilner geto, 19, 36.

34. Lunski, Fun vilner geto, 11, 57-58, 65, 67-69.

35. Epstein, Mekor barukh, vol. 1, 1-2.

36. Quotation from Hirsz Abramowicz, Farshvundene geshtaltn (Buenos Aires: Tsentral farband fun poylishe Yidn in Argentine, 1958), 299; Jakub Wygodski, In shturm: zikhroynes fun di okupatsye-tsaytn (Wilno: B. Kletskin, 1926), 41. 
Reports from the immediate postwar period describe the religious decline among Jews who did not leave Poland and the Pale of Settlement as similar to that experienced by refugees in the east. Upon returning to Vilna from exile in Ekaterinoslav in 1919, Hayim Ozer Grodzienski evaluated the situation as follows:

Even when the days of Haskalah, integration, and assimilation arrived, and when the government issued decrees and fenced in the heders and yeshivas [as if] with hewn stone, none of this was able to inhibit or extinguish the spirit that came from those raised in purity on the fields of Lithuania. . . . However, we have seen what we never believed we would see. A great upheaval took place in a short period of time. The terrible days of war came and the whole world was thrown into confusion. . . . I was shocked to see when I returned to Lithuania that it was twice stricken: its physical and spiritual foundations were torn asunder, and the spiritual destruction was even greater than the physical destruction. ${ }^{37}$

Whatever dangers the modern period had presented Orthodoxy prior to 1914, their effect was insignificant, according to Grodzienski, in comparison with the spiritual havoc wreaked by the war. Whether prewar Lithuania really remained the stronghold of religious purity he claimed it was is open to historiographic debate; perhaps he was consciously (or unconsciously) engaging in rhetorical hyperbole. Even so, the deterioration of religious observance and commitment to Torah study that he encountered upon his return was undoubtedly severe and is confirmed by both secular and religious sources. ${ }^{38}$

\section{The RABbis ReACT}

During the war years, neither Graubart nor Landa was content merely to bemoan declining religious observance, or to polemicize against it. Precisely because the problem was caused by material circumstances rather than ideological or cultural factors, they believed hope remained. They felt that if they could build mikvehs, heders, and other institutions, they could return lost sheep to the fold. Landa wrote that

the refugees in most of these places are dissatisfied with their schools [shkoles] and public kitchens. There are those who are very embittered about this matter and greatly desire its correction, and there are those who understand well that this is not a good thing. Yet, despair has overcome them so that they do not devote their attention and will to it, as with all spiritual matters. However, if one could provide them with a heder or Talmud Torah in the old style, they would certainly wholeheartedly hand over their children to them, except in Zemliansk and Kirtiak, where the refugees are

37. Grodzienski, Ahie'ezer: kovets igrot, ed. Suraski, vol. 1, 121.

38. E.g., Graubart, 162-71, 180-83; Lunski, Fun vilner geto, 8-45 passim, 66-69; Abramowicz, Farshvundene, 299; Roskies, Against the Apocalypse, 133-62, 115-27. 


\section{Andrew N. Koss}

content with the schools and desire only their upkeep, and only a small number can be found there who even recognize the defectiveness of the schools and desire religious education. ${ }^{39}$

Rather than leaping to condemn the refugees, Landa expressed his sympathy for Jews who were unable to obtain religious educations for their children. In a similar vein, he described conversations with children who desired to return to their religious studies. Believing that the majority of refugees preferred religious to secular education, he felt that the decline in traditional education could be reversed.

During his travels, Landa distributed funds put to his discretionary use by his rebbe in order to build or support religious schools and mikvehs. Graubart was simultaneously involved in a similar project and had turned to Grodzienski and other senior rabbis for help. These rabbis realized that a much larger effort would be required if they were to accomplish what they considered to be the rescue of Judaism itself. This effort would involve coordination among and between hasidim and mitnagdim, as well as cooperation with nondenominational Jewish relief organizations. ${ }^{40}$

The mobilization of Orthodox rabbis in response to the crisis brought about major and long-lasting changes in East European Orthodoxy. As much as the war was a destructive event for Orthodox Jewry, it was also an opportunity for creation. It led to the building of new institutions, the expansion of old ones, and fundamental shifts in attitudes toward issues invested with great consequence, especially education. For transformations to occur, the rabbis had to be more involved in communal affairs than ever before.

Part of their response would entail shtadlanut, the petitioning of non-Jewish authorities by distinguished communal leaders. Increasingly, rabbis would engage in this practice themselves, rather than rely on wealthy laymen as had been the long-established practice. ${ }^{41}$ As Graubart did in Staszów, rabbis sometimes engaged in shtadlanut at a local level to prevent violence against Jews or to obtain permission to carry out various religious practices. ${ }^{42}$ But shtadlanut went well beyond the local level. Beginning in the summer of 1916 there was an orchestrated campaign, with Schneerson at its forefront, to exempt rabbis and ritual slaughterers from conscription into the military or auxiliary labor battalions. Petitions to the Ministry of the Interior continued after the February Revolution. Schneerson devoted considerable time and energy to this campaign, and was joined by several prominent mitnagdic rabbis. His numerous letters on the

39. Igrot Rasha" $b$, vol. 5, 69.

40. Ibid., 56-137.

41. For the history of shtadlanut in Russia, see Eli Lederhendler, The Road to Modern Jewish Politics: Political Tradition and Political Reconstruction in the Jewish Community of Tsarist Russia (New York: Oxford University Press, 1989).

42. E.g., An-sky, Der yudisher, in Gezamelte shriftn, vol. 4, 97-101; Graubart, 17; Abramowicz, Farshvundene, 165. It is hard to know whether this sort of behavior was exceptional or widespread. 
subject show that he did not merely delegate the task to a trusted hasid skilled in such dealings, but took an active and hands-on role in the campaign. The fight for the rabbis and ritual slaughterers was not wholly unprecedented, but it was an example of a new kind of political involvement on the part of the highest echelons of rabbinic leadership. ${ }^{43}$

In struggling to protect their fellow Jewish clergymen, rabbis realized that they could no longer rely exclusively on the wealthy, well-connected, and generally acculturated shtadlanim who had represented Jewish interests to the tsarist regime since the eighteenth century, and who dominated major Russian Jewish charitable organizations such as the OPE. In 1914, these shtadlanim mobilized to form the Central Jewish Committee for Relief of Victims of War (EKOPO) in order to coordinate and fund Jewish relief efforts in Russia. ${ }^{44}$ While the rabbinic leadership appreciated the efforts of EKOPO to provide food and shelter for the impoverished Jewish masses, they were also wary of what they saw as EKOPO's secular orientation.

In an effort to release the rabbis and ritual slaughterers from military service, Baron Alexander Ginzburg - a member of EKOPO's board of directors and the archetypal Russian Jewish grandee - and others were sympathetic and willing to help, although never with enough zeal to satisfy Schneerson. Similarly, the Social Revolutionary, Jewish activist, and folklorist S. An-sky spent considerable energy providing Jewish paupers and refugees with kosher food and Jewish soldiers with matzot on Passover. ${ }^{45}$ During this time of unprecedented disaster, both the religious and the secular wished to cooperate. However, the interests and priorities of those who dominated EKOPO and its affiliates were a far cry from those of the rabbis.

Because the war left huge segments of the Russian Jewry dependent on charitable relief, the power of EKOPO and affiliated organizations increased exponentially. Simultaneously, the war shattered local institutions and organizations. Previously, those who wished to reform Jewish life - whether maskilim and assimilationists of the nineteenth century or Zionists, Bundists, and Folkists of the twentieth-had engaged in a protracted struggle with the entrenched power of tradition and its attendant social structures. Suddenly, however, they found themselves in a situation in which they had the upper hand both socially and institutionally. As rabbinic leadership became aware of this shift in the balance of power, the rabbis realized that they had to take immediate action.

Nowhere were the differences between the rabbinate and the relief leadership so stark as in the realm of education. When EKOPO or the OPE established

43. Igrot Rasha"b, vol. 5, 83-119 passim; "Ravviny i voinskaia povinnost'," Novyi put', no. 16 (April 30, 1917):16.

44. Zipperstein, "The Politics of Relief," in Frankel, Studies in Contemporary Jewry," 23-27. Zipperstein emphasizes the collaboration between the wealthy Jewish establishment and a younger generation of activists committed to radical Jewish politics within EKOPO. As far as the rabbis were concerned, both groups were dangerously uncommitted to tradition.

45. An-sky, Der yudisher, in Gezamelte shriftn, vol. 4, 65-66, 69-70, vol. 5, 160, vol. 6, 120-55 passim. 


\section{Andrew N. Koss}

schools for refugees (as Landa and Graubart noted), they created modern schools that emphasized secular over religious studies. After all, the original mission of the OPE was to reform and modernize Jewish education. In response to this problem, rabbis engaged in what might be termed internal shtadlanut, petitioning relief committees to devote equitable funding to religious schools and in general to give proper consideration to religious issues. Rather than condemning the modern schools set up for the refugees in the fire-and-brimstone terms of nineteenth-century antimaskilic polemic, Orthodox leaders merely asked that their own schools receive funding from EKOPO (which channeled money through a variety of other organizations) alongside others.

In the spring of 1916, Graubart, frustrated by previous efforts to gain support from the Moscow Jewish relief council, traveled to Petrograd to petition EKOPO's Central Committee to support his cause. Although the committee was not unanimous in its support for his proposal, it agreed to allocate some funds for traditional schools and mikvehs. A few months later, Grodzienski began relentlessly lobbying EKOPO, and Ginzburg personally, to increase funding for heders and ritual baths, demanding equality between the funding given to traditional schools and that granted to other types of educational institutions. ${ }^{46}$

Even early on, however, the rabbinic leadership did not believe that internal and external shtadlanut would be sufficient to combat the widespread effects of World War I. East European Jewish Orthodoxy would need to develop a new and modern institutional structure that would operate on a national and international level to stay afloat in the current situation. Traditional local institutions, such as the hevra kadisha (burial society) and the hekdesh (poorhouse), were no longer sufficient, or even relevant. The impetus for a new strategy came from the United States. In the fall of 1915, Orthodox Jews in the United States, responding to a desperate letter from Grodzienski and Yisra'el Me'ir Kagan (known as the Hafets Hayim) ${ }^{47}$ established Ezras Torah, a foundation that would raise funds for Jewish clergy in Eastern Europe - rabbis, yeshiva students, ritual slaughterers, and other religious officiants. Just as the war led to the creation of the American Jewish Joint Distribution Committee (JDC) to coordinate fundraising for European Jewry, so too the Orthodox created their own parallel, trans-Atlantic organization. For the first time, the flow of funds from America to Europe was channeled through centralized communal institutions. ${ }^{48}$

46. Grodzienski, Ahie 'ezer: kovets igrot, ed. Suraski, vol. 1, 116-24; Graubart, 38-40, 51-54.

47. The Hafets Hayim (1838-1933), in addition to being a prolific author of rabbinic works, was viewed as a living symbol of saintliness. Although he was even more revered than Grodzienski, it was the latter who had the active leadership role, while the Hafets Hayim himself generally deferred to Grodzienski's knowledge of current affairs.

48. The JDC was founded on November 27, 1914. It was, in fact, the product of a merger between the Central Committee for the Relief of Jews Suffering through the War and the American Jewish Relief Committee. The former was closely associated with the Orthodox leadership and mainly represented East European immigrants and their descendants, while the latter was connected to the more established German Jewish community. Ezras Torah was not meant to be an Orthodox relief organization, but a relief organization designed to meet religious needs. Efraim Zuroff, The 
Ezras Torah's founding documents state that its goal was not to divert money from existing relief organizations (such as the JDC and EKOPO), but to supplement concern for Jews' material well-being with financial support for their spiritual well-being. Furthermore, while Russian rabbis lobbied EKOPO in the name of religious interests, Ezras Torah believed its duty was to lobby the JDC in a similar fashion. Over the course of the subsequent year, as Russian rabbis alerted their American supporters to the nature of the religious crisis, Ezras Torah began directing funds toward solving the problems documented by Graubart and Landa, that is, building mikvehs and heders for refugees and providing for the upkeep of those in the Pale. ${ }^{49}$

In order to properly allocate its funds, Ezras Torah developed a distribution network in Europe. This network was managed not by the prominent laymen who traditionally took on such tasks, but almost exclusively by rabbis. These were not just rabbis who had dedicated themselves primarily to communal affairs, but were also established scholars famous for their talmudic erudition. The oversight committee in Europe consisted of ten distinguished rabbis, including Hayim Soloveitchik of Brisk (1853-1918), Me'ir Simhah of Dvinsk (1843-1926), the Hafets Hayim, Schneerson, and Grodzienski. ${ }^{50}$ Some of these rabbis assumed primarily symbolic roles, and their support of the organization gave it legitimacy in the eyes of potential donors. The correspondence of both Grodzienski and Schneerson shows, however, that the two rabbis were deeply involved in specific questions involving distribution of funds and other organizational details. Furthermore, Ezras Torah had no lay administration; the organizational apparatus in the United States also consisted almost entirely of rabbis. To the extent that it was possible, the European committee engaged local rabbis to distribute funds in their own towns or counties. ${ }^{51}$

As the foundation continued to function after the war, a large segment of the rabbinate in newly independent Poland, Lithuania, and Latvia became part of its organizational structure. This constituted a major shift away from the old system, whereby wealthy and pedigreed laymen (gevirim) conducted the affairs of the community, and rabbis remained aloof, playing only an indirect role or acting as consultants. Even as the rise of relief organizations was changing the power structure of Russian Jewry as a whole, a similar change was taking place within Orthodox Jewry. The formation of Ezras Torah amounted to a declaration of independence from the old elites on the part of the rabbinate; it was also their first successful attempt at organizing on a national level.

Response of Orthodox Jewry in the United States to the Holocaust: The Activities of the Vaad ha-Hatzala Rescue Committee, 1939-1945 (New York: Yeshiva University Press, 2000), 2-4.

49. Ezras Torah, Sefer ha-zikaron: meha-mosad Ezrat Torah (New York: Philip, 1919), 3; Grodzienski, Ahie'ezer: kovets igrot, ed. Suraski, vol. 1, 125-26.

50. Sefer ha-zikaron: meha-mosad, 4. The others were: Refa'el Shapira of Volozhin, Avraham Dov Kahana Shapiro of Kovno, Yehezkiel Lipshits of Kalisz, Mosheh Yeruzalemski of Kielce, and the rabbis of Pressburg and Budapest.

51. Sefer ha-zikaron: meha-mosad, esp. 3-7; Zikaron ba-sefer (New York: Ezras Torah, 1922). See also Kleinman, 235-36. 


\section{From Charity to Politics}

While Ezras Torah did much to support religious life among Russian Jews during and immediately after the war, rabbinic leaders such as Graubart, Grodzienski, and Schneerson wanted to accomplish much more. The idea of creating a national Orthodox league did not emerge overnight. In the nineteenth century, Orthodox Jews in Germany, Hungary, and Galicia each formed organizations to represent their interests in the public sphere. These organizations provided models for future Orthodox politics in the Russian Empire.

In 1907, on the heels of the Russian Revolution, Grodzienski stood at the fore of a campaign to establish a party under the name Keneset Yisra'el (Assembly of Israel). The party was to speak for Orthodox Jewry in the newly created Duma as well as engage in charitable activities and promote Jewish education. Grodzienski also contacted rabbis in Austria-Hungary and Germany with the aim of fusing national groups into a worldwide organization. His efforts, along with those of Isaac Halevy in Germany and Avraham Mordekhai Alter, rebbe of Ger (generally acknowledged as the leader of Orthodox Jewry in Congress Poland), led to an international gathering of Orthodox rabbis in Kattowitz in 1912, which in turn laid the foundation for Agudat Israel (Union of Israel), a global organization that did not truly emerge as a social or political force until after the war. Keneset Yisra'el's activities within Russia were limited by the interference of a reactionary regime and the caution of its own leadership. On the international scene, the outbreak of war put a halt to its activities before much could be accomplished. $^{52}$

The crisis confronting Jewish religious life brought on by World War I, which had led to the formation of Ezras Torah, reinvigorated the efforts of the Russian rabbinate to band together in a social and political organization that would allow rabbis to coordinate efforts and allow Orthodoxy to speak with a unified voice, whether they were addressing the government or Jewish communal leaders. The war's corrosive effects on religious observance and institutions turned the need for such an organization into an emergency; at the same time, the efforts to build heders and mikvehs, the activities of Ezras Torah, and the shtadlanut campaigns (both internal and external) had already brought different segments of rabbinic leadership into close contact, as did the sheer fact of geographic dislocation. These factors, combined with some increased laxity toward civic organizations on the part of the tsarist regime since the outbreak of war, made the time ripe for action. ${ }^{53}$

In January 1917, Graubart traveled to Moscow to meet with Mordekhai Nurok, the exiled rabbi of Mitava (modern-day Jelgava, Latvia), and Refa'el Shelomoh Gotz, an Orthodox gevir, to discuss the idea of forming an association that

52. Bacon, Politics of Tradition, 25-37; Grodzienski, Ahie 'ezer: kovets igrot, ed. Suraski, vol. $1,257-84$.

53. There is now a significant secondary literature on the expansion of Russian civil society during World War I, focused mainly on such semiofficial institutions as the Union of Zemstvos and the Tatiana Committee. See Gatrell, A Whole Empire Walking, 37-48, 75-78; idem, Russia's First World War: A Social and Economic History (New York: Pearson Education, 2005), 38-61. 
would establish and fund "good schools [bate sefer], workshops [where Jews could be apprenticed to learn trades and which would provide a source of income but be closed on Saturdays], and libraries [holding traditional religious literature]. ${ }^{54}$ The situation called for the formation of an ambitious organization that would go beyond the merely charitable activities of Ezras Torah or the strictly political activities of Keneset Yisra'el.

Shortly after the meeting of Graubart, Nurok, and Gotz, revolution broke out in Russia. The tsar abdicated, the provisional government took power, and civil rights were dramatically expanded. An Orthodox league would presumably now have wider latitude to fill its social and cultural goals. Furthermore, the prospect of free elections and the plan to create local, democratically elected Jewish councils and to convene an all-Russian Jewish congress made an Orthodox political party seem a necessity. After Passover (April 7-14), Graubart, Nurok, and Gotz reconvened to get permission from the government to form such an organization, distribute bulletins, and solicit letters of support from prominent rabbis. ${ }^{55}$

A founding congress took place from July 4 through July 11, 1917, in the Poliakov auditorium, located on the upper floor of the Moscow Synagogue. It was attended by a large number of people, including an impressive roster of rabbis, as well as a few laymen. The Hafets Hayim submitted a letter of support, as did several others prominent rabbis. Also in attendance were important observers from the Moscow Jewish scene: the journalist Moshe Kleinman, representing the Zionist movement, and the philanthropist and publisher Hillel Zlatopolski, representing the Tarbut Hebrew school movement. Graubart and Nurok were elected copresidents of the congress. The rabbis of Moscow, Ponevezh, and Kovno, as well as Rabbi Gotz, were elected honorary presidents. ${ }^{56}$

By the close of the conference, an organization-cum-political party was formed under the name Masoret ve-herut (Tradition and Freedom), with a central committee composed mainly of rabbis of important cities, including Petrograd, Kishinev, and Kiev. Grodzienski served in the party as well. An executive committee was formed, consisting of Graubart, Nurok, Gotz, and the chief rabbis of Moscow, Shemu'el Rabinovitsh and Ya'akov Mazeh. ${ }^{57}$ That summer, similar organizations were founded elsewhere in Russia: Netsah Yisra'el (Victory of Israel) in Petrograd, Ahdut Yisra'el (Unity of Israel) in Ukraine, and

54. Graubart, 91; "Ravviny i khedera," Novyi put', no. 4 (January 29, 1917): 27.

55. Graubart, 102-128; Grodzienski, Ahie 'ezer: kovets igrot, ed. Suraski, vol. 1, 284-85; Igrot Rasha"b, vol. 5, 109-112; "Svoboda i traditsiia," Novyi put', no. 16 (April 30, 1917): 27-28. For the sake of simplicity, this date is given according to the Gregorian Calendar; in 1917, Russia still used the Julian Calendar, which, in the twentieth century, was thirteen days behind the Gregorian. For the allRussian Jewish congress, see Mordechai Altshuler, "ha-Nisayon le-argen kinus kelal-yehudi be-Rusyah ahar ha-mahpekhah," He- 'avar 12 (1965): 75-89.

56. Graubart, 106-108, 116; "Etsel ha-haredim," ha-Tsefirah 25 (August 16, 1917): 12.

57. Graubart, 117. Rabinovitsh was the city's unofficial chief rabbi; Mazeh was the government-appointed rabbi (rav mi-ta'am ha-medinah) and a supporter of religious Zionism. Although, unlike most government rabbis, Mazeh had received traditional rabbinic ordination and was a member of the Orthodox camp, the Orthodox community still followed the general practice of having a separate "religious" rabbi. A similar situation existed in Vilna and a few other locations. 
Agudat Yisra'el in Belarus. These were combined under the name Ahdut (Unity) to put forward a united Orthodox front at the scheduled all-Russian Jewish congress, which, however, was never held because of the Bolshevik takeover. ${ }^{58}$ While the February Revolution precipitated the formation of these organizations, they were built on the political and organizational experience that had been acquired since the outbreak of the war.

\section{Masoret ve-hererut and Its Political Platform}

The platform put forward by Masoret ve-herut was not the series of uniformly conservative, antisecularist proclamations one might have expected from an organization led by so many staunchly Orthodox rabbis, many of whom were already or would go on to be closely associated with the emerging haredi (ultra-Orthodox) camp. First, the congress declared its commitment to the reestablishment of the kehilah (Jewish municipal council) on a democratic basis. ${ }^{59}$ In premodern times, almost every Jewish community in Europe was governed by a kehilah, which appointed a rabbi, collected taxes for the upkeep of communal institutions, and served as an intermediary between the Jewish community and the government. In Russia, the institution persisted until 1844, when Nicholas I formally abolished it. The kehilah had been a fundamentally elitist institution, its members possessing both wealth and lineage (yikhes). By the time of World War I, a broad spectrum of progressive Jewish leaders and intellectuals in Eastern Europe - including both friends and foes of Zionism-had embraced the idea of a more democratic type of kehilah. Support stemmed from commitments to nationalism, autonomy, and representative democracy. But why would a congress of Orthodox rabbis, without uniform commitment to Jewish nationalism or democracy, advance such a proposal?

Some of the participants' speeches were colored with the rhetoric of revolution. The vocabulary —out of place in traditional rabbinic discourse-included terms calling for "freedom" or a "new era." 60 Merely using such phrases was a radical step among a group who believed that their values were unchanging and unaffected by the outside world and, furthermore, had learned to regard innovation as inherently dangerous. Yet this sort of rhetoric suggests that some participants genuinely believed that changing times called for a modern-style kehilah. Others took a more pragmatic approach, believing that the kehilah idea would

58. Grodzienski, Ahie 'ezer: kovets igrot, ed. Suraski, vol. 2, 286-87; "Rusyah," ha-Tsefirah 22 (July 26, 1917): 22; "Organizatsiia evreiskoi ortodoksii," Novyi put', no. 21-22 (June 16 1917): 26; "Svoboda i traditsiia," Evreiskaia zhizn', no. 23 (June 25, 1917): 39. See Altshuler, "ha-Politikah," for a detailed analysis of the differences among these parties.

59. Graubart, 118. For a summary of the Masoret ve-herut platform, see "Hit'ahdut ha-yehudit "Herut u-masoret," $h a$ - 'Am, no. 18 (May 21, 1917): 16. A longer version was published as "On di yuden in Rusland," Togblat, 29 May 1917; it is reproduced in Hebrew in Altshuler, "ha-Politikah," 229. It can also be found in both Hebrew and Yiddish in Graubart, 98-103.

60. Graubart, 96-103. Even Grodzienski spoke exultantly of the "light of freedom" (or ha-hofesh) in a public proclamation cosigned by several leading Lithuanian rabbis (Ahie 'ezer: kovets igrot, ed. Suraski vol. 1, 284-89). 
succeed only if phrased in democratic terms. ${ }^{61}$ Finally, many supported democratization because they believed the system would work to their advantage. The founding members of Masoret ve-herut saw themselves as representing the silent majority of Jews who had no party affiliation and continued to live religious lifestyles. $^{62}$ The urgency of wartime relief efforts had given the unelected leaders of the major Russian Jewish charitable organizations a monopoly on political power, ${ }^{63}$ allowing them to do as they pleased while disregarding the wishes and authority of the rabbinic establishment. In such circumstances, free elections would (and did) at the very least ensure representation for the Orthodox, giving them majorities in certain locales. ${ }^{64}$

While taking a strong position on the question of the kehilah, Masoret ve-herut skirted what seemed to many to be the leading issue of the day: Zionism. This issue had particular weight in Moscow, which had been transformed during the war into an important center of Zionism and Hebraism, in part because of the influx of refugees. The city had multiple Zionist and Zionist-leaning periodicals, and hosted the founding conference of the Tarbut movement. Moscow was also a city in which Zionism coexisted somewhat comfortably with traditional religiosity. The government rabbi, Mazeh, possessed traditional rabbinic ordination and was an enthusiastic and active Zionist. Moscow also had several gevirim sympathetic to both Zionism and Orthodoxy. Two of these, Gotz and Yehoshu'a Zelig Persits, were among the most important patrons of Russia's yeshivas and played an active role in the founding of Masoret ve-herut. Another, Zlatopolski, drew upon his considerable financial resources to support general Zionist and Hebraist projects, but was himself religiously observant. ${ }^{65}$

Nurok and Graubart were both committed Zionists, as were many rabbis in prewar Russia, some of whom attended the Masoret ve-herut conference. However, stiff opposition to Zionism also existed in Orthodox circles. Schneersohn and most hasidic rebbes opposed the movement, as did many prominent Lithuanian rabbis. Graubart did not wish to alienate some of the most influential members of the Orthodox elite by making Masoret ve-herut into a platform for religious Zionism. Rather, he and Nurok wished to create an organization for

61. The speech given by Rabbi Yitshak Rabinovitsh of Ponevezh, as recorded by Graubart, expressed an ideological justification for this sort of pragmatism (Graubart, 107).

62. Gershon C. Bacon, "The Politics of Tradition: Agudat Israel in Polish Politics, 1916-1939," in Studies in Contemporary Jewry 2: The Challenge of Modernity and Jewish Orthodoxy, ed. Peter Medding (Bloomington: Indiana University Press, 1986), 146; Landa in Igrot Rasha"b, vol. 5, 69; Graubart, 53-54.

63. Graubart, 118; Yosipon, "Di yudishe ortodoksye in Rusland," 3.

64. See Bacon, Politics of Tradition, 178-280 for the actual successes of the Agudah in local elections in independent Poland.

65. Shmuel Ayznshtadt, "Moskvah ha-'ivrit bi-yeme milhemet ha-"olam ha-rishonah," in Katsir: Kovets le-korot ha-tenu'ah ha-tsionit be-Rusyah (Tel Aviv: Masadah, 1964), vol. 1, 143-57; "Persits, Shoshanah" in David Tidhar, Entsiklopedyah le-halutse ha-yishuv u-vonav (Tel Aviv: 1947-1971), vol. 7, 2824; "Zlatopolski, Hilel," in Tidhar, vol. 18, 5331. Note that Persits's son, Yosef, was married to Zlatopolski's daughter, Shoshanah; the couple were active in Moscow's Hebraist scene. 


\section{Andrew N. Koss}

the protection and advancement of Orthodoxy itself that could compete with other Jewish political parties in democratic electoral politics. Consequently, Masoret ve-herut arrived at a platform calling for support for settlement in Palestine and acknowledging Jewish nationhood as an extension of religious identity-both positions no Orthodox rabbi in Russia could reject. It did not, however, make any mention of Zionism or the creation of a Jewish state. ${ }^{66}$

\section{Reforming Jewish Education}

Masoret ve-herut's support of the democratic kehilah meant a small break with tradition; its approach to Zionism was quite conservative. On the subject of education, however, it arrived at radical positions. Graubart, who had spent the previous years establishing religious schools among refugee communities, gave an impassioned speech on educational reform at the July conference. First, he stated, secular studies had to be introduced into the curriculum of the heder. "The body cannot be nourished by spirituality alone. The soul will not be satisfied with the intangible, and the spirit will not be filled. It is impossible to endure on Torah alone and we need to learn information that is required for finding sustenance. So too, we live in exile and must learn the language of the land." ${ }^{\circ 7}$ Furthermore, he contended, the heder had to adopt modern pedagogical practices, such as dividing students into grades based on age and level of advancement. Graubart also stressed the importance of hygiene: Children must be taught the principles of cleanliness, and schools should be run accordingly. Heders would have the further obligation of moral instruction, eradicating from children's hearts "those bad traits that have clung to us on account of exile," such as brazenness and disorderliness. It would be necessary to establish a pedagogical seminary to train teachers for these new heders. ${ }^{68}$

Since the first half of the nineteenth century, the debate over education had been one of the central controversies within Russian Jewry. Maskilic literature had scorned the heder, with its dirty and stifling setting, its incompetent and cruel melamedim, and its narrow curriculum. Maskilim considered Jews' lack of all forms of secular knowledge an embarrassment, along with Jews' inability to speak any language besides their native "jargon." With the advent of postliberal ideologies, views on education would separate Zionists from Bundists and Folkists, dividing Zionists among themselves, but all agreed on the need to reform the heder radically or abolish it. ${ }^{69}$

66. Graubart 98-100, 107; Y. Himlshtrib, "Ve-'idat 'masoret ve-herut,"” Ha- 'Am, no. 24 (July 12, 1917). Altshuler discusses the negotiations surrounding the issue of Zionism at length in "ha-Politikah," 207-21. On the fundamental conservatism of Masoret ve-herut, see Shmuel Niger, “Svoboda i traditsiia," Novyi put', no. 26 (June 25, 1917), 3-4. In Russia and Congress Poland at this time, even the staunchest Orthodox anti-Zionists believed settling in the Land of Israel to be an act of piety.

67. Graubart, 109.

68. Ibid., 114.

69. For hadarim and heder reform, see Steven G. Rappaport, "Jewish Education and Jewish Culture in the Russian Empire, 1880-1914” (Doctoral dissertation, Stanford University, 2000); 
Graubart's proposed changes in heder education were strikingly similar to those of more moderate nineteenth-century maskilim; his ideal of the new heder was almost identical to the heder metukan, or reformed heder, that had emerged at the turn of the century. Graubart did not wish to diminish the importance of religious education, but he wished to change it significantly. His curriculum proposals did not tamper with the backbone of traditional education: study of the Torah along with Rashi's commentary for younger students, and Mishnah and Talmud for older ones. To this he added structured formal study of the books of Prophets and Writings (often neglected in the heder), ${ }^{70}$ Jewish history (traditionally considered a frivolous topic at best), and Hebrew grammar (which, because of its association with the Haskalah, was sometimes considered mildly heretical when studied or taught formally). Graubart advocated radical change in order to ensure the continuation of Orthodoxy in the postwar era.

Graubart was not wholly typical of the rabbis who participated in the Masoret ve-herut conference, although his high-ranking position shows that he was by no means marginal. His other writings show an intense commitment to religious rejuvenation and to what he regarded as true Haskalah, enlightenment rooted in both religious and secular study, thorough knowledge of Hebrew grammar and non-Jewish languages, and open-mindedness toward new ideas provided that they did not run contrary to fundamental religious teachings. He contrasted this with haskalah ha-meshakelah (enlightenment that bereaves, a Hebrew pun), his term for the antireligious enlightenment. ${ }^{71}$ After the war, Graubart returned to Poland, where he played a leading role in the founding meeting of Shelome Emunat Yisra'el (the Wholeheartedly Faithful of Israel, later the Polish branch of the Agudah) in early 1919. He then left this organization because of its fierce anti-Zionist sentiments and the power it gave to hasidic rebbes, whom he regarded as insufficiently informed about worldly events to be granted such sweeping political authority. ${ }^{72}$ Graubart went on to join Mizrachi (the religious Zionist party) and remained a staunch supporter of religious Zionism after moving to North

Steven J. Zipperstein, "Transforming the Heder: Maskilic Politics in Imperial Russia," in Jewish History: Essays in Honor of Chimen Abramsky, ed. Steven J. Zipperstein and Ada Rapoport-Albert (London: Halban, 1988).

70. See n. 91, below.

71. E.g., Graubart, 173 and 282.

72. Ibid., 183-85. Elsewhere, Graubart criticized the leadership of the rebbes as a divisive and deleterious influence on Polish Jewry, although he excepted certain rebbes, including those of Ger and Lubavitch, from this criticism (165-70, 173-80); see 120-21 for his attitude toward Shalom Dov-Ber of Lubavitch. For Graubart's worldview, see his other published writings, especially Sefer yamin u-smo 'l. The fact that Graubart and hasidic Agudists were willing to consider cooperating with one another in the first place suggests that the split between religious Zionists on the one hand, and what would now be termed the ultra-Orthodox on the other, did not widen significantly until the postwar period-a subject deserving of further scholarly attention. Altshuler ("ha-Politikah") takes for granted a distinction between "datiyim metunim" (religious moderates) and "haredim kitsoniyim" (ultra-Orthodox extremists). Yet such terms are misleading and, particularly in Hebrew, border on anachronistic. Certainly there were moderates and hardliners, but they were generally eager to join forces during the war. 
America. Thus his positions on the subject of education were part of a broader ideological commitment to a liberal version of Orthodoxy.

Graubart's ideas about education were not merely tolerated by the more conservative figures; these rabbis endorsed similar positions immediately after the war's end. Writing from Vilna in 1919, Grodzienski argued in an open letter (the same letter cited above, in which he bemoaned the state of Orthodoxy in Lithuania) that the heder and Talmud Torah would be the front line of the fight for Orthodoxy and the rebuilding of religious life after the cataclysm brought on by the war. He declared that the curricula of these schools must include not only the Pentateuch with Rashi's commentary and introductory study of Talmud, but also the Prophets and Writings, the Hebrew language (lashon ha-kodesh), and elementary secular studies, provided "that sacred studies will be the essential part.",73

Moreover, Grodzienski hoped that the new heders would conform with "the statutes of hygiene [hukei 'higyena'] in spacious room[s] and that there [would] not be a jumble of classes [i.e., that there be separate grades], with expert teachers [melamedim mumhim] worthy of their task, who do their work with faith, who keep the Torah and commandments, and who are knowledgeable about education." ${ }^{, 74}$ The last words refer, in part, to situations associated with the hiring of nonreligious instructors, ${ }^{75}$ but the text also suggests that Grodzienski was quite concerned about the presence of incompetent teachers. He did not support the introduction of such subjects as Jewish history, and showed no sign of agreeing with Graubart about the intrinsic value of secular education, but he nevertheless supported a platform of educational reform, one that would have brought joy to the hearts of many nineteenth-century maskilim (and anger to the hearts of many nineteenth-century rabbis).

Graubart's proposals concerning education stemmed directly from his belief that tradition justified and condoned limited reforms, so long as they left the authority of halakhah and the primacy of Torah study intact. War and revolution both forced the crystallization of his ideas and provided him with a golden opportunity to sell them to the remainder of the religious leadership.

It takes more effort to understand the position of an arch-conservative such as Grodzienski. In 1902, he had issued a proclamation attacking any change in either the curriculum or the pedagogy of the heder, singling out in particular those teachers who wished to employ "methods" (metodot) in instructing their pupils. ${ }^{76}$ His postwar writings do not explicitly contradict his earlier opinions,

\footnotetext{
Altshuler also underestimates the extent to which even more conservative rabbis reconsidered their strategies during the war.

73. Grodzienski, Ahie'ezer: kovets igrot, ed. Suraski vol. 1, 120-24.

74. Ibid.

75. See Zevi Scharfstein, Toledot ha-hinukh be-Yisra'el be-dorot ha-aharonim (New York: 'Ogen, 1945), vol. 1, 380. See also S. An-sky, "I Enlighten a Shtetl," in The Golden Tradition, ed. Lucy S. Dawidowicz (Syracuse, NY: Syracuse University Press, 1996), 306-311.

76. Grodzienski, Ahie'ezer: kovets igrot, ed. Suraski, vol. 1, 111-13.
} 
but nonetheless show a remarkable change in orientation toward educational reform.

Functioning within a milieu where all innovation was considered eo ipso suspect, Grodzienski wrote as if these reforms were not reforms at all. Consequently, he did not make an overt case for why they were necessary, nor did he mention his sources for such changes as the division of students by age or for improving hygiene. It is likely that the passage of time had made these ideas seem more acceptable and less extreme, especially because secularists had moved on to more radical demands. ${ }^{77}$ However, the connection he established between the effects of World War I on religious observance and the need to establish and maintain new schools implies that these reforms represented something more: a new and necessary strategy for combating secularization.

Before analyzing the origins and purpose of heder reform, it is necessary to look at another, perhaps even more radical, change in Jewish education that won broad endorsement from Orthodox rabbis during the war: formal religious education for women. Prior to the war, women in traditional households generally received only informal religious education; occasionally they were taught by private tutors. Only rarely could they understand the Bible or prayers in Hebrew; textual knowledge was usually limited to books in Yiddish intended especially for women. Then again, it was not uncommon for girls from religious families to receive secular educations while their brothers attended heder and yeshiva. ${ }^{78}$

During World War I, this discrepancy between the genders came to be seen in Orthodox circles as a serious social problem that encouraged women to forsake religious observance. It was felt that the situation could be remedied through the setting up of schools that taught girls the Bible in Hebrew, traditional moral and ethical works, practical halakhah, and secular subjects (the study of Talmud remained off-limits to women). In German-occupied Vilna, the acting chief rabbi, Yitshak Rubinstein, presided over the creation of a strictly Orthodox girls' school. ${ }^{79}$ Rubinstein was similar to Graubart in outlook, and had garnered respect inside and outside Orthodox circles. ${ }^{80}$ And as was the case with other internal reforms, the idea of Orthodox education for girls gained traction among

77. See Shmuel Feiner, Preface to Me-haskalah lohemet le-haskalah meshameret: mivhar mikhteve Rash"'i Fin (Jerusalem: Merkaz Dinur, 1993) for background to this type of phenomenon.

78. Deborah Weissman, "Bais Yaakov: A Historical Model for Jewish Feminists," Studies in Jewish Education 7 (1995): 278-99; Shaul Stampfer, "Gender Differentiation and Education of the Jewish Woman in Nineteenth-Century Eastern Europe," in From Shtetl to Socialism: Studies from Polin, ed. Antony Polonsky (Washington, DC: Littman Library of Jewish Civilization, 1993), 271-89.

79. Abramowicz, Farshvundene, 167; Sefer-zikaron leha-rabanit Ester Rubinshtein: kovets ma'amarim be- Ivrit ve-Yehudit, ed. Sh. L. Tsitron (Vilna: Bet ha-defus shel B. Tsiyonson ve-shutafav, 1925).

80. Abramowicz, Farshvundene, 163-70; Klausner, Vilnah, vol. 1, 100-303 and vol. 2, 361-87 and 527-654, passim. Rubinstein, much like Mazeh, had both traditional and modern educations and had served as government rabbi of Vilna until 1915. His appointment to this post, orchestrated by Grodzienksi, had been considered an Orthodox victory over the city's maskilim. After Grodzienski fled, Rubinstein became the leading rabbinic figure. For the postwar conflict between the two, see Gershon C. Bacon, "Warsaw-Radom-Vilna: Three Disputes over Rabbinical Posts in Interwar 
more conservative figures as well. The Hafets Hayim, a figure of unmatched prestige among Lithuanian mitnagdim, also came to support the idea during the war.

After the war ended, a network of schools named Bet Ya'akov actually put the idea of Orthodox girls' schools into practice in independent Poland. This organization had originated among Galician refugees in Vienna around 1917, under circumstances analogous to those experienced by refugees from the Pale in the Russian interior. ${ }^{81}$ By 1919, Agudat Israel of Poland had endorsed Bet Ya'akov; in 1923 the Agudah's first international conference made the support and expansion of Bet Ya'akov schools a major plank of its platform, largely because the schools' endorsement by the Hafets Hayim and prominent hasidic rebbes had granted them legitimacy. ${ }^{82}$

In addition to public statements on the topic, the Hafets Hayim provided halakhic justification for this radical change; he did so in a footnote within a talmudic work published in 1918 (and thus written during the war). Although it is unclear whether he received the idea from developments in the Habsburg lands or from some other source, his line of argumentation suggests a powerful reaction to contemporary developments, and thus his note is worth quoting in full:

\begin{abstract}
It appears that all this [the prohibition against teaching women even the written Torah] applied specifically to times before ours, when each person dwelt in the place of his forefathers and ancestral tradition was very powerful for every person, so that everyone would conduct himself according to the path trod by his fathers. As Scripture states, "Ask your father and he will tell you" [Deuteronomy 32:7]. In such a condition they were able to say that [a woman] should not study Torah and should rely on her elders for guidance, but now, because of our many sins, ancestral tradition has been greatly weakened, and it also happens that one does not live in the place of his fathers at all; specifically, it is a great commandment [mitzvah] to teach those women who study the writing and language of the nations the Pentateuch, and also the Prophets and Writings, and the ethical teachings of the Sages ... in order that the idea of our holy faith be accepted by them as true [she-yit'amet etslam 'inyan emunatenu ha-kedoshah]. Otherwise they would be apt to stray completely from the way of God and transgress all the fundamentals of Torah, Heaven forbid! $!^{83}$
\end{abstract}

Here the Hafets Hayim states quite explicitly that he is granting a lenient ruling in response to historical circumstances. During the Russian retreat, he and his

Poland and Their Implications for the Change in Jewish Public Discourse," Jewish History 13, no. 1 (1999): 103-126.

81. For the overall situation of these refugees, see Marsha L. Rozenblit, Reconstructing National Identity: The Jews of Habsburg Austria during World War I (New York: Oxford University Press, 2001), 59-81.

82. Bacon, Politics of Tradition, 164-76.

83. Yisra'el Me'ir ha-Kohen, Likute halakhot, Sotah 11a-11b (Piotrków, 1918). See Soloveitchik, "Rupture and Reconstruction," 107 n. 6, for the significance of this passage in the history of halakhic reasoning. 
students had fled Radun (where he had lived for most of his adult life) and were forced to relocate several times over the next few years ${ }^{84}$ - a stark contrast to "times before ours, when each person dwelt in the place of his forefathers." Although he did not mention the war outright, given the time of writing and his own experiences, it is likely that this phrase referred to the effects of mass flight and expulsions and was written in response, in some way, to the crisis of observance brought on by the war. At a time when the structure of traditional life had been broken, radical means were necessary to maintain faith and social order. Although secularization and assimilation had been potent threats prior to the outbreak of war, support for women's education had been extremely marginal within Orthodox circles. After the war, though, it became all but universal.

The Hafets Hayim's halakhic argument was somewhat atypical in its forthright acknowledgement of change and its vaguely Weberian description of the end of traditional society (in fact, had he not had such powerful bona fides as a conservative scholar and icon of piety, he would have been unlikely to dare offer such a bold argument). But other rabbis' endorsements of Bet Ya'akov were similar in that they saw the schools as the only means to prevent a mass defection of the entire female sex.

Furthermore, there are strong reasons to believe that the rabbinic leadership also endorsed women's education as a way of combating the problem of prostitution among Jewish women. The severe economic conditions in the territories occupied by the Central Powers, combined with the large numbers of soldiers stationed there, made the incentives high for some women (both Jewish and non-Jewish) to turn to prostitution to support themselves. Prostitution and pimping were also widespread themes in Jewish literary fiction of this period; evidence suggests that this preoccupation reflected reality. ${ }^{85}$ Although I have found no mention of prostitution in religious literature regarding the war, this silence can easily be explained by reluctance to speak openly about such a scandalous and unseemly topic; it does not mean that rabbis were unconcerned. While lack of hard evidence limits a connection between women's education and prostitution to the realm of conjecture, it is very likely that some rabbis who lent their support to Bet Ya'akov were motivated by a desire to keep girls off the streets, in addition to

84. David Zariz, "Yeshivat Radin," in Mosedot Torah be-Eropah, ed. Samuel K. Mirsky (New York: Histadruth Ivrith of America, 1956), 191-95.

85. See Steven E. Aschheim, Brothers and Strangers: The East European Jew in German and German Jewish Consciousness, 1800-1923 (Madison: University of Wisconsin Press, 1982), 146-48; Avrom Virshubski, "Dos folksgezunt un der meditsinisher lebnsshteyger in Vilne beshas der daytsher okupatsye," in Pinkes far der geshikhte, 86-88; Lunski, Fun vilner geto, 8, 50-51; An-sky, Der yudisher, in Gezamelte shriftn, vol. 4, 215 and vol. 6, 30; Vejas G. Liulevicius, War-land on the Eastern Front: Culture, National Identity and German Occupation in World War I (New York: Cambridge University Press, 2000), 80, 133, 186. For literary depictions, see Roskies, Against the Apocalypse, 116-21. Most notable is perhaps Oyzer Varshavski's Shmuglars: A roman in dray teyln (Warsaw: Kultur Lige, 1921), a novel about life in Poland under German occupation. At the very least, the ubiquity of the theme of prostitution in fictional works suggests that Jews perceived it to be widespread. 
wishing both to counteract a more general decline in observance and to combat the proverbial problem of young women knowing more Tolstoy than Torah.

The support for multipronged educational reform-including the introduction of secular subjects, changes in the teaching of sacred subjects, the opening of schools for girls, and hygienic and pedagogic improvements - by Grodzienski and the Hafets Hayim, and the vast majority of the mitnagdic Lithuanian rabbinate who were willing to follow them, thus stemmed largely from practical considerations. Because wartime circumstances had shut down heders on a massive scale, the playing field between traditional and secular schools had been leveled. Previously, the OPE had to fight against inertia and tradition to get parents to send their children to its schools. But for those who had gone into exile to places where heders were unavailable, the taboo against nontraditional education had been broken. Similarly, children who stayed in Poland and Lithuania often did not attend school at all during the war years. When various secular organizations started their own schools after the war, they were competing with an Orthodox community scrambling to reopen the heders. In other words, Orthodoxy lost the entrenched position it had occupied before the war. Under these circumstances, alternatives to the heder seemed quite compelling even to parents who were not committed ideologically to Zionism, Bundism, or assimilation.

The debate stirred by the Masoret ve-herut conference further illuminates how conservatives came to favor moderate reforms. When Schneerson refused even to attend, in part because a proposal to establish an Orthodox gymnasium was on the agenda, ${ }^{86}$ Rabbis Eli'ezer Rabinovitsh of Minsk and Yitshak Ya'akov Rabinovitsh of Ponevezh attempted to win him over with an unusually blunt justification for compromise. They wrote to him that they, too, had been opposed to the idea, until they realized that members of their flocks would send their children to gymnasia no matter what, and that the only course of action was to establish an acceptable alternative ${ }^{87}$ The upheaval of the war led to a situation where, as the Hafets Hayim wrote, tradition alone was not enough to keep people in the fold. Active competition became the order of the day.

In addition to the need to compete, there was a fundamental shift in the goals of heder education during this period. Not surprisingly, the sources do not make this shift explicit. In Grodzienski's letter about rebuilding Jewish education, he stresses that despite the importance of creating and supporting secondary and advanced institutions - the Talmud Torah, yeshiva, and kolel-elementary schools were to take utmost priority. Graubart's memoirs and writings from this period show a great preoccupation with the heder, and he makes only scattered mention of places of higher learning. Maintaining the heder stood out as a key issue in the correspondence of European rabbis with Ezras Torah in America during and immediately after the war. ${ }^{88}$ Similarly, Landa's report to Schneerson engendered serious interest in elementary education on the latter's part during

86. This was not Schneerson's only reason; see below.

87. Graubart, 118-21; Igrot Rasha"b, vol. 5, 109-12.

88. Sefer ha-zikaron: meha-mosad and Zikaron ba-sefer. 
the war years. This is particularly notable in light of Schneerson's correspondence immediately before the war, in which he expressed great concern about the Lubavitch Tomkhe Temimim yeshiva and its affiliates, but hardly mentioned heders. ${ }^{89}$ The wartime crisis of the heder, much greater than the threat from maskilic reformers of the prewar period, gave the institution new attention and led to a reconceptualization not only of its curriculum, but also of its role.

The traditional heder of Eastern Europe had not been particularly successful at imparting anything but the most rudimentary religious education to its students. At the very best, graduates could be expected to have gained familiarity with the Pentateuch and segments of the Prophets, an understanding of these texts' Hebrew idiom, and knowledge of prayers and their meaning. Many came away with even less. The heder was not an effective forum for the teaching of Talmud; often the teachers themselves did not understand this difficult text well and rarely possessed useful pedagogic tools for introducing it to students. Children from wealthy or learned families often received instruction from private tutors. The heder was, however, quite effective in preparing young males for participation in Jewish society, guaranteeing that most knew enough to follow along in the synagogue service and read the Torah with Yiddish translation and commentary. The heder also served to separate the wheat from the chaff: Those students who demonstrated facility with Talmud despite the pedagogical stumbling blocks might be sent on to yeshiva, an elite institution reserved for the select few. The others would be imbued with a sense of the difficulty of Talmud study and would feel awe for those who could master it. ${ }^{90}$

The new emphasis on the heder's importance and the moderate changes (by external standards) proposed to its curriculum bespoke not only an internalization of maskilic critiques but also a reevaluation of the heder's goals. The new Orthodox schools could (at least in theory) provide children with a more complete basic education in Judaism, rather than merely practical training in how to be a male member of Jewish society. Actual instruction in the Hebrew language (instead of rote recitation of the Torah) and a few strategies borrowed from modern Western pedagogy would give children a better chance of graduating with a firm grasp of the fundamentals of Judaism as conceived by Orthodox rabbis.

Graubart also wished to increase the emphasis given to the Prophets and Writings in the elementary curriculum, and seems to have had Grodzienski's support in this matter. ${ }^{91}$ Study of these books would expose the masses to religious

89. Compare Yosef Yitshak Schneerson, Igrot-kodesh (Brooklyn, NY: Otsar ha-hasidim, 1985), vol. 1, 2-56 (hereafter Igrot Rayya "ts) with Igrot Rasha 'b, vol. 5, 149, 151-52, 157, 165-66. The elder Schneerson was already well attuned to the heder because of his participation in the controversy over the establishment of a heder metukan by the OPE in Lubavitch itself in 1899 (Rappaport, "Jewish Education and Jewish Culture," 214-20).

90. Zipperstein, "Transforming the Heder" in Frankel, Studies in Contemporary Jewry; Shaul Stampfer, "Heder Study, Knowledge of Torah, and the Maintenance of Social Stratification in Traditional East European Jewish Society," in Studies in Jewish Education III (1988): 271-89.

91. Given the reluctance to argue for innovation as such, it is difficult to know whether Grodzienski's explicit mention of the teaching of the Prophets and Writings (not just the Pentateuch) is a call to give these subjects a greater role in the heder curriculum. These books were frequently (but not always) taught in traditional heders prior to World War I, but usually such instruction was limited to 
texts that could be inspiring, religiously edifying, and even entertaining, but, unlike Talmud, did not require years of rigorous study to penetrate. Teaching Jewish history (a change too extreme for many) could further a sense of pride in Jewish identity. Serious Talmud study would remain the province of the yeshiva.

Grodzienski, Graubart, and their supporters believed that in a world torn asunder by war, a higher level of religious education could keep people in the fold (of course, these rabbis took it as a matter of faith that study of sacred texts led to piety and religious observance). Their attempt to reform primary schooling for boys emerged simultaneously with their move to educate women. The Hafets Hayim's writings in justification of teaching women could also justify new ways of teaching men.

The heder reforms introduced during and after World War I were not the first steps taken by East European Orthodoxy to respond to the threats posed by the modern age, but they were aimed at the masses in a new way. Shaul Stampfer has argued that the yeshiva, in its new form that emerged with the foundation of the Volozhin Yeshiva at the beginning of the nineteenth century, was created as a response to modernization. Its original goal was to improve the training of future members of the social elite; later on, it aimed to shield potential members of this elite from insidious outside influences during their formative years. Similarly, the musar (ethical introspection) movement of Yisra'el Lipkin of Salant, which sought to confront new threats to religious life through a reformation of the inner world, spoke exclusively to yeshiva-educated elite. ${ }^{92}$ (Musar began to undergo a transformation into a mass movement in the years after World War I. $)^{93}$ Postwar reforms in elementary education, conversely, were directed toward the entire Jewish youth population, without regard to intellectual, monetary, or family status. They were not intended to develop a religious intelligentsia, but rather to instill a new norm, universal across East European Jewry, in knowledge of and orientation toward Judaism, and, in turn, to preserve a society that was in danger of disintegrating.

\footnotetext{
the Psalms and a few of the Early Prophets. Melamedim were often unable to translate the difficult Hebrew of the Prophets and Writings. Although the Prophets and Writings tended to be taught more frequently, and more thoroughly, in Lithuanian heders than those elsewhere, it was still rare for them to be taught extensively. See Obshchestvo dlia rasprostraneniia prosveshchenie mezhdu evreiiami v Rossii, Sovremennyi kheder (St. Petersburg: 1912), 15-18, 38-39, 65-66, 78-79. It is difficult to tell from this report whether the heders in which these books were taught were in fact hadarim metukanim. See also Abramowicz, Farshvundene, 387. Nokhum Shtif, describing his childhood in Rovno (Volhynia) in the 1880 s, wrote that "studying the Prophets and Writings was equated with nonbelief - all the more, studying Hebrew grammar" ("How I Became a Hebrew Writer," in The Golden Tradition, ed. Lucy S. Dawidowicz [Syracuse, NY: Syracuse University Press, 1996], 257).

92. Stampfer, ha-Yeshivah, 18-20, 314-15.

93. David E. Fishman, "The Musar Movement in Interwar Poland," in The Jews of Poland between Two World Wars, ed. Yisrael Gutman et al. (Lebanon, NH: University Press of New England, 1989), 247-71.
} 


\section{Contextualizing Wartime Reforms: Limits and Legacy}

Although many of the educational reforms discussed here were remarkable because they were supported by a very broad spectrum of the Orthodox rabbinate, they were not universally accepted. It is important to emphasize that Masoret ve-herut did not succeed in co-opting all of Russian Jewish Orthodoxy. The rabbis who signed its initial charter hailed overwhelmingly from either historic Lithuania and the adjoining provinces of Livland and Kurland or from areas fresh to Jewish settlement-New Russia and places outside the Pale. Furthermore, rabbis who remained in areas that came under German occupation were cut off from events in Russia, and thus were excluded from Masoret ve-herut. Within these parameters, support was widespread and included future members of both the Zionist Mizrachi and anti-Zionist Agudist camps.

The most glaring exception was Schneerson, who refrained from attending the congress although he was on good terms with both Grodzienski and Graubart, even after he had taken part in the deliberations leading up to it. ${ }^{94}$ His opposition, as mentioned earlier, stemmed primarily from Masoret ve-herut's interest in supporting an Orthodox, Hebrew-language gymnasium. He had participated in the 1912 Kattowitz Conference and in the formation of Ezras Torah, and continued to be involved in efforts to unite and organize Orthodox Jewry in Russia. In the summer of 1917 (shortly after the Masoret ve-herut conference), he was one of seven rabbis selected to serve on a leadership committee for Orthodox Jewry in Russia. Nevertheless, he maintained a certain skepticism about the formation of a vast, unified, Orthodox organization, primarily because of his fear of infiltration by non-Orthodox or what he considered imperfectly Orthodox elements. ${ }^{95}$ As an alternative, he attempted to consolidate the internal organizational structure of the Lubavitch community in a way that paralleled developments among mitnagdim. ${ }^{96}$

Although it would be wrong to extrapolate from the Lubavitch case to other hasidic groups, Schneerson's wartime activities show that the developments within Orthodoxy did cross the hasidic-mitnagdic divide. As for the other hasidic groups of Lithuania (e.g., the courts of Karlin-Stolin, Slonim, and Kapust), or those of Volhynia and Podolia, the historical record is too sparse to lead to any conclusions (indeed, little documentation exists on Orthodoxy in the latter areas at all during this period). In general, mitnagdim were somewhat quicker to encourage heder reform, but during the 1920s many of these reforms came to hasidic communities as well. ${ }^{97}$

The developments discussed above also have parallels in other regions of Eastern Europe. At the same time that Lubavitch Hasidim and Russian mitnagdim created modern institutions operating on a national level, German Agudists came

94. For his attitudes toward the Agudah prior to World War I, see Igrot Rasha' $b$, vol. 2, 335 and vol. 5, 8-15, 42-47. Graubart's opinion of him remained high, despite their differences. See n. 72 above.

95. Ibid., vol. 5, 56-58, 109-126; Grodzienski, Ahie 'ezer: kovets igrot, ed. Suraski, vol. 2, 643. 96. Igrot Rayya"ts, vol. 1, 42-45, 100-110, 114-19.

97. Bacon, Politics of Tradition, 142-77. See also Aescoly, 122-32; Shaul Stampfer, "Hasidic Yeshivot in Inter-War Poland," Polin 11 (1998): 3-24. 
to German-occupied Poland and collaborated with the local rabbinic leadershipdominated by hasidic rebbes - to build Orthodox political organizations. The occupation regime broadened freedom of assembly and organized local elections, giving Agudat Israel an important role. ${ }^{98}$ Although Jews in the Habsburg lands lived under greatly different circumstances before and during World War I, it is worth noting parallels here as well. Jews from Galicia, Bukowina, and Transylvania, who were overwhelmingly traditional, fled to Vienna, Prague, and other cities ahead of advancing Russian troops in 1915. Their contact with these cities' Westernized Jews seems to have aided their political and organizational development in a similar fashion. ${ }^{99}$ As the secular Zionist leader Yitshak Grünbaum neatly summarized in 1918, "the war on the one hand, and the [Russian] Revolution on the other, forced Jewish Orthodoxy to emerge as a political force virtually in all lands with a large Jewish population." 100

It is a truism among historians of the Jewish religion that Orthodoxy is a modern phenomenon, not an exact replica of what had existed before 1750, as both its most fervent proponents and most fervent detractors have often claimed. In particular, historians of Orthodoxy have emphasized the transition from an unselfconscious traditional society to a self-consciously traditionalist one. ${ }^{101}$ The political, organizational, and educational changes discussed here are all key elements of this transition and, in varying ways, brought this transition from the elite to the masses. Historians have tended to understand the changes that have taken place within Orthodoxy as responses to the Reform and Haskalah movements, political and legal emancipation, fundamental characteristics of modernity itself, and the physical destruction of the heartland of traditional Judaism in Europe during World War II. All elements of this evaluation are correct, but they overlook a crucial factor in the East European case, namely the transformative effects of World War I.

98. Alexander Carlebach, "A German Rabbi Goes East," Leo Baeck Institute Yearbook 6 (1961): 60-121; Mordecai Breuer, "Rabanim-doktorim be-Polin-Lita bi-yemei ha-kibush ha-germani (1914-1918)," Bar-Ilan 24-25 (1989): 117-53; Viktor Shulman, "In di yorn fun der Ershter velt milkhome," in Di Yidn in Poyln: fun di eltste tsaytn biz der Tsveyter velt milkhome (New York: Farlag "Unser Tsait," 1946), 806-11, 863-66; Bacon, Politics of Tradition, 37-46. See also Ezra Mendelsohn, Zionism in Poland: The Formative Years, 1915-1926 (New Haven, CT: Yale University Press, 1981), 43-49.

99. Jess Olson, "Nathan Birnbaum and Tuwiah Horowitz: Friendship and the Origins of an Orthodox Ideologue," Jewish History 17 (2003): 1-29; Rozenblit, Reconstructing National Identity, 70-80. Note also that Sarah Schenirer, founder of Bet Ya'akov, reported getting the idea for a network of religious schools for girls while a refugee in Vienna.

100. Y. Kanoi [Yitshak Grünbaum], "Di ortodoskye als politishe kraft," Unzer togblat 119 (July 26-August 8, 1918), 1. The same article also appeared in Dos yudishe folk 40 (October 3, 1918), 1-3.

101. See Moshe Samet, "The Beginnings of Orthodoxy," Modern Judaism 8, no. 3 (1988): 24969; Silber, "The Emergence of Ultra-Orthodoxy," in Wertheimer, Uses of Tradition, especially 26 n. 4; Katz, "Orthodoxy in Historical Perspective," in Medding, Challenge of Modernity. Both Silber and Katz identify World War I as a breaking point in the history of East European Orthodoxy but do not discuss how or why this was so. 
The new Orthodox organizations that emerged during the war increased the power of the rabbinate at the expense of the traditional lay leadership while simultaneously offering a new role for the common folk. Voting for an Orthodox party in kehilah, municipal, and national elections was a form of active identification with a self-consciously religious (as opposed to secular, not as opposed to impious) community. Similarly, the reforms of the heder were meant to ensure that children whose parents made the decision to send them to religious schools (which had ceased to be the default option) in addition to or instead of secular ones would be more likely to graduate with greater Jewish knowledge, the kind of knowledge one would expect from an ideologically committed member of a group.

Such changes within East European Orthodoxy mirrored the changes without. On the Polish- and Russian-Jewish street, World War I saw nationalist and socialist parties transform from underground networks to active political and social forces with mass appeal. For Jews' Polish neighbors, it was in the decade 1905 to 1915 that national movements took on a mass character. ${ }^{102}$ Similarly, in 1917, the newly formed Soviet Union began a project of creating an entire society of ideologically committed communists. ${ }^{103}$ Thus, some of the changes that Orthodox Judaism underwent during World War I can be seen as part of the advent of mass politics in Eastern Europe.

In the part of Europe where the erosion of traditional Jewish life was the slowest and where religious observance remained the rule rather than the exception into the twentieth century, it took the sudden and cataclysmic events of World War I-a war in which Jews suffered expulsions, impoverishment, and massacres - to catalyze some of the most important changes within East European Orthodoxy, changes that remain in Orthodox Judaism today. In the face of this crisis, the rabbinic leadership not only decided to mobilize its resources and go on the political offensive, but also tacitly accepted some of the criticisms of its enemies.

\author{
Andrew N. Koss \\ Brooklyn College \\ New York, New York
}

102. See Robert Blobaum, Rewolucja: Russian Poland, 1904-1907 (Ithaca: Cornell University Press, 1995).

103. Particularly insightful analyses of this aspect of the Soviet regime can be found in Jan T. Gross, Revolution from Abroad: The Soviet Conquest of Poland's Western Ukraine and Western Belorussia (Princeton: Princeton University Press, 2002), 91-113, and Steven Kotkin, Magnetic Mountain: Stalinism as Civilization (Berkeley: University of California Press, 1995). 